\title{
THE PROBLEM OF INDIVIDUAL'S BIOSOCIAL INTEGRITY AS AN OBJECT OF PHILOSOPHICAL STUDY
}

\section{Romanenko S. S.}

\section{INTRODUCTION}

The nature of man is an eternal problem for man, existing for himself from the moment of the biosphere development, when this development at a certain stage created the prerequisites for a special the next type of evolution - emerging and developing human society. Socio-philosophical and even just philosophical understanding of this problem did not arise immediately. But - what is man? what is the world? and what is the place of man in this world? - people turned to these questions by virtue of their cognitive activity. Our recourse to the history of mankind allows us to notice the transformation of man's views on the universe with the accumulation of the practice of interacting with nature, communicating with each other, expanding collective memory.

At the turn of the 21st century, a situation arose in scientific knowledge when the irreversibility of entering a new way of thinking manifested itself quite clearly; when the complexity and supercomplexity of the world and man himself were determined, it became necessary to present in a new light the future of the movement of knowledge about oneself, other possibilities of using it in thinking and activity of new generations.

Today, the problem of studying the biosocial integrity of an individual has gained global status, and these problems of the present have increased the interest of science to man, the interest of man to himself as an enduring value. The anthropological component of understanding the world has gained particular importance which determined the urgency of the problem of our study, the main task of which is to study the biosocial integrity of an individual.

The formation of the conception of man's biosocial integrity as the basis for the formation of a unified science about Man is possible under the condition of continuous replenishment with the latest data from comprehensive scientific research and modern methodological tools. 
This will allow us to characterize the place, role and sense significance of the problem of individual's biosocial integrity at the present stage of the scientific thought movement to comprehend the nature of the noosphere level of our planet development and the development of people living on it.

\section{The formation of society's views on the world, the nature of man and his place in the world}

The nature of man is an eternal and ever new problem. Throughout the history of their existence, people have been thinking about the meaning of life, their place in the world, their life purpose, their kinship with the natural world, through highlighting their past history, they tried to comprehend the forces and connections of society, to look into its future. The fruits of the intense spiritual work of the best minds of mankind laid the foundation for the future science of Man.

Recent studies have noted that it was I. Kant who was the first to argue that "through a person one can reach other philosophical problems", and that this was an attempt to present the doctrine of man in a systematic form, but in the Kantian interpretation of practical anthropology (1798), the existence of the external world and the objectivity of things surrounding man was not shown. The very appeal to this side of knowledge about man was seen by I. Kant as "a scandal for philosophy and universal human mind"1. Probably, this moment was meant by M. Mamardashvili, who emphasized that in the description of man in philosophical anthropology all directly human things available to us were eliminated, allowing to provide a description of the image of a particular man through their properties. This image is always built on abstractions ${ }^{2}$.

I. Kant's arguments at the time of the Enlightenment proved the utopian nature of the idea of a unified science. He regarded man as a dualistic creature split into pairs of incompatible opposites. Man was seen at the same time as both a phenomenon and a "thing in itself", an empirical and transcendental being, a phenomenon and a nomenon.

\footnotetext{
${ }^{1}$ Петриківська О. С. Філософська антропологія як методологія синтезу знань про людину: автореф. дис. ... канд. філос. наук: 09.00.02. Одеса, 2007. 18 с.

2 Мамардашвили М. К. Картезианские размышления. М.: Прогресс, 2001. $352 \mathrm{c}$.
} 
This kind of duality of man later received a direct response in the ideas of postmodernism.

It just so happened that everything that scientific thought could cognize was knowledge of the human-measured world. This was noted, fixed and emphasized by D. Hume in his famous "Treatise on Human Nature" with the following words: "There is no significant issue whose solution would not be part of the science of man, and no such issue can be resolved with any certainty before we get to know this science" $[169, \text { p. } 56]^{3}$.

The first attempt to create a "unified science of man" was made by the creators of the French Encyclopedia D. Didro and J. L. D'Alembert. In the classification of sciences proposed there, they also expressed confidence that the division of sciences is feasible provided that the subject of research and knowledge of it is distinguished.

In the 19th century, the positivists O. Comte and G. Spencer expressed their commitment to the idea of a unified Science. This was supported by the popularity of Darwin's doctrine of evolution, naturalistic calls for creating a "genuine" science about man, similar to the natural sciences, the orientation toward the natural and scientific explanation of society. On the part of advocates of humanitarian knowledge who did not want to hear about the transformation of the humanities into a subsection of sciences about nature, i.e. of natural science, these ideas were followed by a fierce rebuff of V. Dilthey, G. Rickert et al., who argued that neither in their subject matter nor methodologically humanities can be commensurate with the endlessly mathematized classical natural science.

"In the veins of the cognizing subject constructed by J. Locke, D. Hume and I. Kant, not real blood flows, but liquefied juice of the mind as bare mental activity" 4 . This popular figurative phrase from the most famous work of V. Dilthey "Introduction To the Science of the Spirit" expresses an acutely intolerant criticism of the sources of European rationalism that gave rise to it. Contrasting the humanitarian knowledge defended by him (which he himself never called so),

\footnotetext{
${ }^{3}$ Юдовская А. Я. Эволюция права в государствах Европы и Америки (XVII ХІХ вв.). СПб.: Спец. лит., 1996. С. 56.

4 Дильтей В. Введение в науки о духе. Собрание сочинений: в 6 т. М.: Дом интеллект книги, 2000. Т. 1. С. 274.
} 
V. Dilthey clarifies his psychological position as follows: "my historical and psychological studies are devoted to man as a whole ...". And he adds that he means "man in the diversity of his powers and abilities, this is a willing-feeling-imagining being",

In such an atmosphere of confrontation, the idea of unification, even of a certain comparative analysis of subject fields etc., was out of the question. One way or another, but over the past century, the opposition of natural knowledge to the humanitarian and their "supporters" continued to make itself felt in the writings of researchers on the European continent. And yet, there were exceptions. Thus, in the famous book of the philosopher and anthropologist A. Gehlen "On the Systematics of Anthropology" the possibility of the emergence of "a science about man in the full sense of the word" is proclaimed, that is, it affirms the "all-encompassing", philosophical nature of this science, which differs from the morphology, physiology, physiology of feelings, psychology, which are also devoted to man, "studying certain aspects of this most complex object of all objects and, if possible, distracting from all others", . Philosophical anthropology, according to A. Gehlen, perceives man as a whole using the material of these separate sciences ${ }^{8}$. In the middle of the 20th century, the split manifested itself again, especially when discussing the problem of man, his integral biosocial essence. In fact, integrity just did not receive recognition from either the structuralists or the hermeneutists. But these were the same years when more and more new results of research in the natural sciences were generalized - this contributed to the emergence of global evolutionism, evolutionary psychology, sociobiology, etc. A counterbalance to them was the beginning of an emerging new humanistic science about man.

The outstanding thinker and humanist of the 20th century Erich Fromm keenly felt the tension of the historical moment and expressed hope and confidence that the best minds of mankind would give their

\footnotetext{
5 Дильтей В. Введение в науки о духе. Собрание сочинений: в 6 т. М.: Дом интеллект книги, 2000. Т. 1. С. 317.

${ }^{6}$ Гелен А. О систематике антропологии. Проблема человека в западной философии. М.: Прогресс, 1998. С. 151-201.

${ }^{7}$ Гелен А. О систематике антропологии. Проблема человека в западной философии. М.: Прогресс, 1998. С. 156.

${ }^{8}$ Ibid.
} 
strength to a single new humanistic science of mankind ${ }^{9}$. Agreeing with him, academician I. T. Frolov, the creator of the powerful "philosophy of global problems" movement in Eastern Europe, proclaimed the problem of man to be one of the global problems of our time and called for a theoretical study of this problem, which is most important for all mankind. "When man with his own hands created a situation where he is able to destroy himself, he begins to realize the need to create a unified science of man as a dialectically contradictory and changing integrity" $" 10$. But it was precisely at the turn of the $60 \mathrm{~s}$ and $70 \mathrm{~s}$ of the last century when a deep contradiction, literal confrontation, hostility, split between the two cultures - naturalscientific and humanitarian - were observed rather acutely.

The origins of this split can be considered referring to the prescientific history, to the first forming research attempts and even the first philosophical reflections of the ancient Greeks. It was there where a reflection of the researchers on the course of turning to the subjects of study and its results was noticed for the first time, where formulated generalizations already appeared and the contours of the natural sciences took shape, where the need for explanation and description of what is revealed in man became tangible. But very soon the inapplicability of those cognitive means that acted in relation to the subject field of physics, chemistry, biology, if used in humanitarian research, was discovered. This meant that the terminological apparatus focused on mathematical samples and a proof-deductive text design was not used at all. An example is the main work of B. Spinoza, which he called "Ethics Outlined in Geometric Order"11. The author expressed his commitment to geometry in the fact that the entire text of the work was constructed in the form of theorems, each followed by a proof and a series of examples.

The followers of $\mathrm{R}$. Descartes were characterized by the interpretation of the human body like a clock work. In T. Hobbes' studies, the state model showed its similarity to the organism of any living creature. There are some cases mentioning that historians

\footnotetext{
${ }^{9}$ Фромм Э. Вклад Маркса в познание человека. Философия и общчество. 1998. № 3. С. 234-250.

${ }^{10}$ Фролов И. Т. Избранные труды: в 3 т. М.: Наука, 2003. Т 3.: О человеке и гуманизме. 2003. С. 745.

${ }^{11}$ Спиноза Б. Собрание сочинений: в 2 т. М.: Госполитиздат. Т. 1. 1957. 640 с. 
rationally criticized even religious history - they "cleaned out", if possible, the lives of saints that contradict the laws of physics.

The idea born in the works of V. Dilthey and F. Schleiermacher, about the need to distinguish between sciences of the nature and sciences of the spirit, continued to develop not only in the 19th and 20th centuries, it has been still actualized from time to time today. But we must assume, in connection with the profound transformation of epistemology, in a situation of urgent need for "building bridges" between (we shall use the words of V. Dilthey) the "sciences of the nature" and "sciences of the spirit" and at the intersection of these "bridges" we are to have a deep understanding of the problem of biosociality as a human essence. We still have to think about what gave rise to the split in the two cultures, why the confrontation of sciences (remember "lyricists and physicists") was shaped as a tradition and how it can be eliminated from our thinking.

The Russian philosopher, our contemporary M. A. Rozov, in the course of an in-depth analysis of humanitarian problems, allowed himself to conclude about a "stable tradition of contrasting the natural sciences and the humanities, a tradition that has retained its significance despite all the changes and refinements made so far." Moreover, as he noted, the humanities faced very specific methodological problems that made it difficult to directly compare them with the natural science ${ }^{12}$.

In the subject of sciences, called the sciences of the spirit, the facts of spiritual life are not separated by us from the psychophysical life unity of human nature. The theory which claims to describe and analyze socio-historical facts, "has no right to be distracted from this wholeness of human nature and to provide and limit itself to the spiritual sphere" ${ }^{, 13}$.

The problem of the biosocial integrity of an individual is interdisciplinary in nature and, naturally, turning to it leads us to philosophical anthropology because of the commitment of the latter to overcome fragmentation in the ways people are viewed in philosophy, biology, psychology, medicine and sociology.

\footnotetext{
${ }^{12}$ Розов М. А. Строение научного знания (проблемы методологии и методики анализа). Философия науки. М.: ИФРАН, 1997. С. 63.

${ }^{13}$ Дильтей В. Введение в науки о духе. Собрание сочинений: в 6 т. М.: Дом интеллект книги, 2000. Т. 1. С. 282.
} 
Recently, numerous scientific areas have emerged, each of which characterizes itself as an "anthropology" with one or another specification, and each of the "branch" anthropologies makes a statement - to reveal the foundations of human life and claims to become the foundation of a single science about Man. Within the framework of a certain generalized concept of man, a number of variants of methodology for integrating scientific knowledge about man arose. Thus, to begin with, a specific scientific discipline is proposed for the role of the foundation in creating a single theoretical "image" of man. For example, modern biology has claimed the desire to become the theoretical basis of the whole complex of sciences about man, human society and human culture. Today, on this basis, a whole complex of new scientific directions and areas has arisen: biopolitics, bioepistemology, biolinguistics, evolutionary ethics, evolutionary epistemology.

Certain humanities, primarily anthropology, also claim to have a unifying synthesis of all human sciences.

In English-speaking countries, anthropology is understood as a set of scientific disciplines that study humanity at all historical stages of its development. As a rule, "physical anthropology, archeology, anthropological linguistics and cultural anthropology belong to anthropology"14. In the American, British and French traditions, when using the term "anthropology", they mean the allocation of a certain subject area, the subject approach. All types of anthropology are distinguished from the philosophical approach by highlighting a specific area of research, as well as focusing attention, on the one hand, on the biological and cultural differentiation of various groups of people, on the other hand, on those integrative features that allow us to represent mankind as a whole. At the same time, anthropological disciplines are united by a number of general scientific principles and methodological approaches, among which the "principle of integrity" stands out. Unlike philosophy, anthropological scientific knowledge always refers to a specific subject area, for example, to culture. When R. Jacobson proposes linguistics as a paradigm for a unified science of man, he explains this primarily by the extremely regular and closed structure of the language and the important role that it plays in culture. "Linguistics is," he writes, "the most advanced and accurate science of

${ }^{14}$ Философская энциклопедия: ХХ век. М.: АСТ, 2001. С. 40. 
man and, therefore, is a methodological model for the rest of related sciences" $"$.

In contrast to the various concepts of the philosophy of nature presented in the history of philosophy, where nature was considered outside and independently of man, in the studies of R. S. Karpinskaya and her supporters, the development of nature is directly related to the development of man, there are universal, fundamental foundations that permeate and determine the whole process of development. The human-sizedness of all natural science concepts is revealed, from these positions their value orientation, the degree of ralizing humanistic attitudes in them are analyzed. It turns out to be possible to do this by highlighting the methodological role of the idea of coevolution presented in its universal content, reflecting the mechanism of linking development, evolution of material systems at all levels of the universe. It was assumed that the idea of co-evolution can become a new paradigmatic attitude of the culture of the 21st century, a powerful source of new research programs for the future - a new philosophy of nature, a new cultural studies, a new philosophy of science $^{16}$.

\section{Individual's biosocial integrity, its study as a problem of science and philosophy of 21th century.}

The course of events of the 20th century leads to a new comprehension of the problem of man. The efforts of modern researchers are aimed at finding and highlighting in human activity the basis for understanding the place of man in the world.

Since in each abstraction certain moments of human activity are focused, modern approaches contribute to understanding the real place of man in the world. However, these approaches themselves are not equivalent in terms of adequacy, their models and concepts of the essence of man. Thus, the concept of the noosphere put forward by V. I. Vernadsky (1863-1945), introduces the universal perspective of the supraorganismic study of man, since it includes his activity in the context of planetary connections. V. I. Vernadsky overcomes the Robinsonade on his planetary scale. Not a single person, but the

\footnotetext{
15 Якобсон Р. Избранные работы. М.: Прогресс, 1985. С. 317.

Карпинская Р. С. Биология, идеалы научности и судьбы человечества. Вопросы философии. 1992. № 11. С. 139-149.
} 
mankind as a whole acts as a geological factor, relatively new in time. In addition, mankind is a special factor, in the form of world history mankind appears as an active force where intellectual potential, thinking and mind, goal-setting and goal-reaching play a unique and decisive role.

In line with these interests, a new direction in the sciences of man - bioethics appeared. It is characterized, first of all, by realizing the value of life, the moral sanctification with life as a fundamental value. Its efforts are directed mainly from man to the world sorrounding him, and the goal of these efforts is to preserve this life, regardless of the form in which it exists. That is why the range of interests of bioethics includes such moral issues as euthanasia, organ transplantation, artificial insemination, genetic design, cloning, biomedical research, etc. The point of bioethics as a special kind of intellectual activity and social practice is to try to discover the possibilities of dialogue and solidarity of citizens in protecting good and opposing evil in situations generated by modern biotechnology. The practice of bioethics is gradually forming the language of public discussing of the most urgent vital problems in people, explaining in fundamentally different ways what is true and what is false. Citizens can now differently realize their unity and assert their unique presence in it. Thus, a new dimension of the "self" is formed, which in an equal dialogue can discover the specific unique meaning of one's existence for another and at the same time, within the same openness, discover the unique meaning of the other "self".

The emergence of bioethics marks a transition to a deeper understanding of previously acquired theoretical material in the field of human relations, the emergence of moral awareness, the essence of moral problems in connection with new realities and practical possibilities for their implementation. Such an understanding requires going beyond a narrow subject area (biology, medicine), significantly expanding the understanding of the subject of moral relations. Based on the system of key values - life, health, death, childhood and old age - it includes not only ethical standards of the doctor-patient relationship, but also ecological ethics: attitude to animals, biocenoses, and the biosphere as a whole. This means that not only man, but all nature are subject to moral ties and moral regulation, 
radically expanding and deepening the foundations of traditional morality as the moral of "reverence for life"17.

Human activity can be considered as a game (see J. Heysing "The Man Playing"), but one cannot reduce man's entire life to a game, although the game moment is present in human activity. Man's "self" can be regarded as a "complex mental process", , but it must be remembered that every individual is something immeasurably greater than the most complex mental process. The idea of an individual as a multi-level hierarchical supersystem for processing information from six components (sensory, motor, cognitive, affective, style and value subsystems) departs from reality in the key thing - it presents part as a whole, completely identifies informational activity with all life activity. With this one-sided understanding of human activity, the needs and relationships of individuals take reduced forms: a real, practical attitude to the world, inclusion in material life relations is replaced by an incomplete, local, random, superficial opinion about this activity. The inadequacy of such particular models interpretations of the essence of man - reveals the concept of a "manpragmatist" (a practical man who knows how to do, act without thinking). A pragmatist is a person who processes, interprets information and strives to make quick, rough, ready-made decisions in complex and uncertain situations ${ }^{19}$.

Among modern human models, we should note computer and information models which are organically connected with scientific and technical revolution. Scientific and technical revolution forces man to learn to combine two heterogeneous streams of information, one of which is still entirely in the power of the subject, and the other is represented by streams of information that operates in technical systems outside and regardless of the decision maker. Computerization presents humanity with a new serious test. On this basis, a "hardware worldview" and various versions of "computer utopias" arise. A number of authors speak in this connection of a fundamental change in the very nature of man. So, J. Bolter discovered in the Western culture of the computer age the emergence

\footnotetext{
${ }_{17}^{17}$ Швейцер А. Благоговение перед жизнью. М.: Прогресс, 1992. - 572 с.

18 Хейзенга Й. Homo ludens. Человек играющий: В тени завтрашнего дня. М.: Прогресс, 1992. С. 217.

19 Хейзенга Й. Homo ludens. Человек играющий: В тени завтрашнего дня. М.: Прогресс, 1992. С. 248.
} 
of "Turing Man", which is a fundamentally new phenomenon of people. However, the "Turing Man" is a beautiful metaphor for an epistemological image that, so to say, merged with a computer, for whom the display overshadowed and replaced the entire outside world. He sees only the screen and interacts only with his keyboard. Playing countless informational games, he feels himself to be the creator of the worlds. His power over these worlds is greater than that of the absolute monarch, even than the "prohibitions of nature" in our physical world and in the activities of the natural scientist who is forced to strictly observe them. Nevertheless, when transforming information, a programmer deals with the real world, although, as with non-computer information transformation, he operates with a model in the processes of cognition and goal-setting. New modeling possibilities opened by modern information technologies fit into the structures of human activity and improve it. However, the ultimate focus on the objective world and its transformation in the interests of man remains decisive ${ }^{20}$.

In the aspect that interests us, the contemporary discussion of this problem is somewhat in tune with the efforts and direction of V. I. Vernadsky's thoughts to understand man in his cosmic dimension, in connection with the whole cosmic world. Thus, in the evolution of the human model an important role is given to the chosen scale of consideration and methodological settings of the worldview ${ }^{21}$.

Man in the framework of a natural scientific approach is a natural body, an individual, Robinson. The next scale is social: a citizen, a political animal, the totality of social relations, supraorganic unity and integrity. The planetary approach opens a new layer in the concept of man, requiring the development of other logical and instrumental means for theoretical reproduction in consciousness.

Philosophical anthropology in the broad sense of the word appears as a philosophical doctrine of man, his "essence" and "nature", which represents a variety of philosophical trends, offering according to their conceptual principles, various ways of understanding man and the human world. Philosophical anthropology

20 Болтер Дж. А. Человек тьюринга: западная культура в компьютерный век. Социология культуры: современные зарубежные исследования. М., 1987. С. 67-114.

${ }^{21}$ Вернадский В. И. Научная мысль как планетарное явление. В. И. Вернадский о науке. Дубны: Изд-во «Феникс», 1997. Т. 1: Научная мысль. 576 с. 
as a philosophical trend originated mainly from Germany having spread to Austria and Switzerland (A. Gehlen, H. Plesner, M. Scheler). Philosophical anthropology as a special philosophical discipline has been dealing with human issues for the past five decades. It is actively constituted from a general philosophical discourse with a specifically own "object" and "thematism" of its consideration (man in philosophical reflection, a doctrine of man, his essence and nature $)^{22}$.

The most important question of philosophical anthropology is the search for the definition of man. No less urgent are the questions of the nature of man, the meaning of his existence, the difference between man as a form of life and other forms, or about a specific human way of being. Regardless of whether one or another philosophy of man proceeds from "spirit", "soul", "freedom", "personality", "being", "salvation", "existence", "life", etc., in all cases, the search unfolds in one direction - in the direction of defining what man is. Philosophical anthropology is ultimately nothing more than a study of the structures of the specifically human experience of the world, and the study does not come down to a description of this experience, but involves a critical clarification and justification.

Philosophy of the 20th century offered many images of man expressed by such metaphors as animal rationale (rational animal) (for example, by D. Davidson), animal symbolicum (symbolic animal) by E. Cassirer, homo ludens (playing man) by J. Hazing, homo pictus (the man who draws, depicts) by G. Jonas, homo viator (the wanderer man) by M. Marcel, homo insciens (inept man) by H. Ortega-i-Gasset, homo creator (man-creator) by V. E. Mühlmann.

The rapid accumulation of specific scientific knowledge about man in modern conditions supplements the comprehension of man in contradictory and ambiguous philosophical concepts, creates the conditions for a qualitatively new understanding of man himself. At the same time, man ceases to identify himself with any form of his being and comes to the realization of the unity of all possible forms of existence (past, present, future). The "homo faber" among positivists, the "dionistic man" by F. Nietzsche, the idea of man as a "disease of life" in pan-romantic teachings, the "homo sapiens" by C. Linnaeus,

${ }^{22}$ Абдушенко В. Л. Философская антропология. Новейший философский словарь. Мн.: Книжный Дом, 2003. С. 1095-1097. 
the "man of power only" by N. Machiavelli, "only libido" by Z. Freud, "only the economy" of K. Marx, the idea of the fallen godlike Adam. This representation of metaphor definitions is given by V. I. Veriaskin, who emphasized that "all these ideas are too narrow to encompass the whole person. All of them are, as it were, ideas of things that understand man as an object. But man is not a thing, he is the direction of movement of the universe itself, he is a microcosm and a spiritualized living being" 23 . All these ideas are really narrow, for they lead away from the holistic vision of a multidimensional man. But many methodological developments of anthropological philosophy can now help modern man in self-understanding, selfinterpreting himself in comprehending not in proposed contradictory, ambiguous characteristics, but in contradictory, opposing each other and yet not separable their own properties.

Two main paradigms can be distinguished in anthropological philosophy of the 20th century - the paradigm of "life" and the paradigm of "being", or "existence". The first goes back to F. Nietzsche, the second - to S. Kierkegaard. The paradigm of life is associated with highlighting the fact that man is a vital being, and therefore - an integral part of life (that is, ultimately, natural) process. The basis of the second paradigm is formed by S. Kierkegaard's thesis about man as a "self". On the one hand, man as a "self" is the result of his own "becoming", on the other hand, he finds himself in being as something that has already "become".

Two program works as early as in 1928 formed the basis of philosophical anthropology - "The Position of Man in Space" by M. Scheler ${ }^{24}$ and "Steps of the Organic and the Human" by H. Plesner ${ }^{25}$ who is considered the true pioneer of modern philosophical anthropology. H. Plesner suggested exploring man not as a "body" (an object of the objectifying procedures of natural science), not as a "soul" or "consciousness" (an object of psychology) and not as an abstract subject dependent on laws of logic

\footnotetext{
${ }^{23}$ Веряскина В П. Императивы экологической этики и новый образ человека. Синергетическая парадигма. Человек и общество в условиях нестабильности. М.: Пресс-Традиция, 2003. С. 267.

${ }^{24}$ Шелер М. Положение человека в космосе. Проблема человека в западной философии. М.: Прогресс, 1988. С. 31-95.

${ }^{25}$ Плеснер Х. Ступени органического и человек: Введение в философскую антропологию. М.: РОСПЭН, 2004. 368 с.
} 
and ethical norms, but as psychophysically neutral unity of life. Philosophical anthropology by $\mathrm{H}$. Plesner is part of a very broadly conceived philosophical and methodological project, which is supposed to remove the splitting of knowledge into natural and human sciences. Its goal is "to recreate philosophy in the aspect of substantiating life experience in the science of culture and world history"; an important, but not the only means of such justification is a phenomenological description. Philosophical reflection should be aimed at human life experience as a whole, and not only at the experience of natural science. The concept of life at the same time covers not only socio-cultural, but also natural and organic forms. The place of the "subject" opposing the outside world is occupied by the "organism" and its environment" or "life plan". The problem of transcendental unity of apperception is replaced by the problem of the relation of the body to its own boundary. Philosophical anthropology according to $\mathrm{H}$. Plesner, can only be built together with philosophical biology. What is needed is not the affirmation of the "special situation" of man in outer space, not the juxtaposition of the human to the natural, but the search for the essential definiteness of man in comparison with other living beings. The founder of philosophical anthropology as a science proceeds, again as opposed to the dualism of traditional teachings - not from conceptual dichotomies, but from the correlation of life spheres (there are three of them - plant, animal and human). From here emerges the phenomenology of the forms of life organization in which man acts as a part, or one of the steps in the "stepped structure of the organic world".

A. Gehlen, also recognized as a classic of philosophical anthropology in his treatise "Man. His Nature and Position in the World" (1940) rejects "metaphysics", i.e. speculative philosophical tradition in general. He does not just intend to understand the phenomenon of man, without resorting to categories such as "spirit", "soul", "mind", "subjectivity" or "existence", but also to build man's philosophy based solely on the philosophy of nature. The starting point of Gehlen's anthropology is man as an unrooted animal in nature, deprived of a firm position in the world ${ }^{26}$. The fundamental

26 Гелен А. О систематике антропологии. Проблема человека в западной философии. М.: Прогресс, 1998. С. 151-201. 
difference between man and other living beings consists in "insufficiency", man, as I. Herder once defined him, is "insufficient creature" (Mangelwesen); the basic properties of an "insufficient creature" are instinctiveness and non-specialized sensory organs. This encourages man to work; its result and at the same time a condition for its possibility is the artificial world of culture. Culture (language and technology) becomes that specifically human environment (Umwelt), the only one where this helpless creature can survive.

V. S. Styopin is sure that the history of human sciences per se begins in the 19th century, "when the attitude to various human qualities as objects of management and transformation was clearly formed in the culture of technogenic civilization" 27 . The attitude to any investigated phenomena and processes as objects is an indispensable condition of the scientific method of cognition. In the era of industrialism, an object-object relationship to a person and human communities becomes dominant in anthropogenic culture.

In the era of the technogenic civilization formation and development, a great many social practices arose that changed the basis of the organizational life of traditional societies and formed a technical and engineering approach to man. In the production and social spheres of life, the general principle of "knowledge-power" was implemented. The man here was already considered as an object that needs to be investigated and rationally regulated. "Such practices and discourses formed and reinforced a new attitude towards an individual as an observable object, described and regulated by certain rules" 28 . This material was accumulated, comprehended, forming the sociocultural prerequisites for the formation of the social and humanitarian sciences. For a long time, knowledge about man, features of his behavior, ways of life, etc., were systematized and explained through sociophilosophical schemes. The corresponding meanings were fixed in the universals of culture, in the understanding of man, creating the prerequisites for the emergence of social and humanitarian sciences, for the formation of their foundations and methods. At the same time, thanks to improved tools and new

27 Степин В. С. Генезис социально-гуманитарных наук (философский и методологический аспекты). Вопросы философии. 2004. № 3. С. 38-39.

28 Степин В.С. Генезис социально-гуманитарных наук (философский и методологический аспекты). Вопросы философии. 2004. № 3. С. 38-39. 
methods of research, a whole field of objects and processes was revealed that made it possible to enter into a description and analysis of living creatures of nature. At present, there is an active growth of biological knowledge, its transformation into science.

In the context of the discourse about man, human nature, his nature, the basic dimensions of his being, the new European concept of man is sharply opposed by postmodernism with its special position. The goal of postmodernism is genuine knowledge about man; in this knowledge, philosophy plays a leading role, making knowledge about man its main subject. Regarding this, there is a saying about the breakthrough of the ancient Greek sophists who made in the 5th century BC. a similar attempt to change the approach to the subject of philosophy, to change the perspective of man's vision and, therefore, to find new knowledge about him ${ }^{29}$. Postmodernists turn to an aesthetic worldview, give an aesthetic representation of man with his general characteristic of a "wanting person", i.e. a creature that accepts every moment of his life as desirable, chosen by himself. Today, researchers compare this appeal with the arbitrariness of P. Feyerabend ${ }^{30}$. In order to return man to himself, an orientation has been adopted to the irrational, sensual-emotional, on the animal's liveliness, on his physicality, eroticism, gender, postmodernism.

Postmodernism today is already leaving the stage, but continues to tease many people and provoke a sharp and emotional backlash. We can explain its phenomenal success by the fact that postmodernism has affected important aspects of human existence. In fact, it declared war on the traditional humanistic ideas as not reflecting the daily needs and concerns of modern man, setting the task - to give man himself back, to give him back his lost dignity. We focus on the arguments of postmodernism, for all this relates to the revision of the problem of human integrity. The previous concept proceeded from the idea of man reasonably critical, responsive, with mental stability. But in the new conditions of life, characterized by extreme instability, exacerbation of all global crises, it is necessary to

29 Алейник Р. М. Человек в философском постмодернизме. М.: МИК, 2006. C. 23 .

${ }^{30}$ Никифоров А. Л. Методологическая концепция П. Фейерабенда. Bonpocbl философии. 1976. № 8. С. 142-146. 
revise the idea of human nature. Postmodernism wants to give a person freedom, and in its understanding this means taking a person out of the power of society, becoming out of politics, becoming above circumstances. Man should squeeze out of his mind the idea of the social world with its problems and see only the world of passions that meet or do not meet his expectations. Such a "recipe" is antisocial in nature and serves as an expression of weakness and infantilism of the social position of postmodernism. However, the principle of diversity (heterogenesis) proposed by postmodernism should be taken into account by a humane society. It is necessary to pay attention to the abilities of the subject that serve his purpose: his desires, physicality, activity, language. And this means a completely new understanding of sensory experience, the phenomenon of corporeality and a radical rethinking of the phenomenon of spirituality. The structure of self-positioning, the life-meaningful guidelines of man, are also changing. Today, the nature of human experience and human behavior is in the process of change which is caused by structural changes in society: there is a shift in the labor demarcation in the context of the formation of new communities and their modernization.

Postmodernism in its desire to describe the position of man in the context of globalization, which had a tremendous impact on the economy, politics, culture, revealed the human essence in a new way and raised the question of humanity in the current conditions. Of course, it did not solve these problems. However, by clearly indicating them, postmodernism thereby helped humanity realize them. So that man could regain himself, earn to enjoy life again. So that he could regain the ability to independently make judgments, and not lose his own dignity. So that he could ask questions, learn to hear the answers of others. So that he could in the new conditions remind politicians of their responsibility for the future. So that the leading principle in the relations between peoples could become the principle of friendliness, and not confrontation, because humanity can only survive as a community. This is the meaning of this new humanism ${ }^{31}$.

The birth of post-non-classical science was marked by a continuous series of radical transformations carried out by the

31 Алейник Р. М. Человек в философском постмодернизме. М.: МИК, 2006. $224 \mathrm{c}$. 
changed natural science itself and, of course, by restructuring the scientific picture of the world. Man's place in nature and a worthy place in the Universe, in the scientific picture of the world, as well as the problem of the conflict of "two cultures" (natural science and humanitarian), under the influence of new data, a new understanding of nature by the first decade of the 21st century had gained new significance. These new data and methodological reflection on their results not only substantiated a strong version of the anthropic principle in cosmology, but also found traits that are close to earthly life and man, and contributed to the inclusion of both man and human culture as organically interconnected parts of a universally unified Universe in the emerging scientific picture of the world and nature ${ }^{32}$.

We consider it possible and necessary to show that, on the same basis, literally in the last two decades, there have been significant advances in clarifying the problems of biosocial integrity and human value. The rapprochement of the natural and social is extremely promoted by biology, which throughout the past century was confirmed by such sciences as zoopsychology, ethology, primatology, sociobiology, evolutionary psychology.

Modern studies of animals' cognitive abilities and intellect have made a "real" revolution in the ideas of animals' abilities - their consciousness, self-awareness, communication, culture - the very barrier factors that separate, as it was believed, humans from the animal kingdom, i.e. first of all, labor (the manufacture of tools for the production of tools) and language. The decoding of communicative situations and natural languages of bees, ants, as well as the cognitive abilities of highly social animals, makes an adjustment in assessing their memory, awareness of problems, making decisions, expressing hope, etc. This statement in recognition of the "humanity" of animals has been supplemented to date with even more staggering indicators of sociobiology (which arose after the 60s, also called evolutionary anthropology), which showed a common mechanism for the formation of social forms of behavior in animals and man, their single internal biological nature in man himself, and therefore, developed in the process of anthropogenesis and was fixed at a non-genetic level.

\footnotetext{
${ }^{32}$ Борзенков В. Г. Человек в современной научной картине природы. Многомерный образ человека: на пути к созданию единой науки о человеке / под общ. ред. Б. Г. Юдина. М.: Прогресс-Традиция, 2007. С. 210-213.
} 
V. G. Borzenkov summarizes that "such many models of behavior as jealousy, anger, greed, love, compassion and even self-reflecting consciousness, the pursuit of sense can be considered as the result of our internal biological nature" and we can add - as a phenomenon of isomorphism, confirming the dual-integral nature man himself ${ }^{33}$.

Such a model of the integral, containing in its foundation purposefulness and axiologicality as indispensable features of this whole proves that human activity and purpose, and value are extremely important and significant. Moreover, as V. G. Borzenkov rightly emphasizes, the model of human characterization, which is undeniably confirmed by the latest achievements of biology at the macro and micro levels of research, will lead us to a fundamental change in understanding of the nature as a whole. Today, the philosophical consideration of living systems of any level in terms of their "expediency", the correspondence of their structure and functioning to the goals of survival and reproduction is indisputable ${ }^{34}$.

Success gives rise to new problems along this path: today, the disproportionately increased volume of already existing knowledge outstrips the level of its understanding and development. Science is informationally overloaded, the task of increasing the capacity of knowledge and compressing information is becoming ever more acute. This task, according to the founder of the synergetic paradigm of new science G. Haken, can be solved "by moving from the need to consider the action and behavior of individual parts $\langle\ldots\rangle$ to the description of the entire system"35. The academician L. L. Kiselev regarded new section of biology which had become a reality - human biology - as the contribution of biology to the solution of this problem. "We have reached a new level of man's knowledge," he noted, "now relying on his biological properties. Philosophers, social scientists, and sociologists should interact as closely as possible with the new biology so that such a complex phenomenon as man can be cognized comprehensively, from different sides, in the totality and interaction of his biological and social principles. It will be mutually

\footnotetext{
33 Ibid.

34 Борзенков В. Г. Теология в современной биологии. Высшее образование в России. 2003. № 5. С. 24-29.

35 Хакен Г. Основные понятия синергетики. Синергетическая парадигма. Многообразие поисков и подходов. М.: Прогресс-Традиция, 2000. С. 42.
} 
interesting,"36. This will require a significant change in the techniques, methods, approaches in the study of becoming objects, rethinking, and sometimes re-discovering of their already known properties, clarifying of the meaning of old concepts, introducing of the new ones.

\section{CONCLUSIONS}

The analysis of the formation of ideas and views on the biosocial integrity of an individual in the historical aspect, as well as the study of its emerging nature, made it possible to present society, the individual and his biosocial integrity not as a result, but as "a result together with its formation". Incompleted and, possibly, unable to be completed biosocial integrity, self-realized by an individual in society, acts as a source of further society development.

The problem of the biosocial integrity of an individual at the present stage of the science development is considered in the context of the analysis of individual's interaction with the social environment, his activity and the specific impact of socializing institutions, in which an individual is included throughout his life. The most widespread understanding of the essence of the biosocial integrity of an individual in modern studies can be interpreted as the process of the most complete identification and realization by an individual of his abilities, achievement of goals in solving personally significant problems, which allows an individual to realize his biosocial potential to the fullest extent possible.

Although the concept of biosocial integrity is quite widely used in the scientific field, today there is practically no in-depth analysis of the ontological and epistemological foundations of the biosocial integrity of an individual and the influence of social space on the indicated property of an individual. We believe that the problem of individual's biosocial integrity as an object of philosophical study is most adequately studied in the framework of the natural environment for an individual - society and its structural elements - small groups of society.

\footnotetext{
${ }^{36}$ Киселев Л. Л. Парадоксы биологии человека. Многомерный образ человека: на пути к созданию единой науки о человеке / под общ. ред. Б. Г. Юдина. - М.: Прогресс-Традиция, 2007. С. 200.
} 


\section{SUMMARY}

The study is based on the understanding of the concept of biosocial integrity of man as the basis for the formation of a unified science about man, which is possible under the condition of continuous replenishment of the latest data from complex scientific research and in the presence of modern methodological equipment. The article attempts to present a transformation of man's views on the universe as the practice of interacting with nature, communication, and the collective memory expansion. The author carried out the analysis of the formation of views on the biosocial integrity of an individual in the historical aspect studying its forming nature. This made it possible to present society, an individual himself and his biosocial integrity not as a result, but as "a result together with its formation". In the context of society's views on the world, the nature of man and his place in the world, the role and sense significance of the problem of the biosocial integrity of an individual in the 21st century were characterized. The problem of individual's biosocial integrity at the present stage of the science development is considered in the context of analysis of individual's interaction with the social environment, his activity and the specific impact of socializing institutions.

\section{REFERENCES}

1. Абдушенко В. Л. Философская антропология. Новейший философский словарь. Мн.: Книжный Дом, 2003. С. 1095-1097.

2. Алейник Р. М. Человек в философском постмодернизме. М.: МИК, 2006. $224 \mathrm{c}$.

3. Болтер Дж. А. Человек тьюринга: западная культура в компьютерный век. Социология культуры: современные зарубежные исследования. М., 1987. С. 67-114.

4. Борзенков В. Г. Теология в современной биологии. Высшее образование в России. 2003. № 5. С. 24-29.

5. Борзенков В. Г. Человек в современной научной картине природы. Многомерный образ человека: на пути к созданию единой науки о человеке / под общ. ред. Б. Г. Юдина. М.: Прогресс-Традиция, 2007. С. 201-220.

6. Вернадский В. И. Научная мысль как планетарное явление. В. И. Вернадский о науке. Дубны: Изд-во «Феникс», 1997. Т. 1: Научная мысль. 576 с. 
7. Веряскина В П. Императивы экологической этики и новый образ человека. Синергетическая парадигма. Человек и общество в условиях нестабильности. М.: Пресс-Традиция, 2003. C. $266-279$.

8. Гелен А. О систематике антропологии. Проблема человека в западной философии. М.: Прогресс, 1998. С. 151-201.

9. Дильтей В. Введение в науки о духе. Собрание сочинений: в 6 т. М.: Дом интеллект книги, 2000. Т. 1. С. 270-730.

10.Карпинская Р. С. Биология, идеалы научности и судьбы человечества. Вопросы философии. 1992. № 11. С. 139-149.

11. Киселев Л. Л. Парадоксы биологии человека. Многомерный образ человека: на пути к созданию единой науки о человеке / под общ. ред. Б. Г. Юдина. - М.: Прогресс-Традиция, 2007. С. 193-200.

12. Мамардашвили М. К. Картезианские размышления. М.: Прогресс, 2001. 352 c.

13.Никифоров А. Л. Методологическая концепция П. Фейерабенда. Вопросы философии. 1976. № 8. С. 142-146.

14.Петриківська О.С. Філософська антропологія як методологія синтезу знань про людину: автореф. дис. ... канд. філос. наук: 09.00.02. Одеса, 2007. 18 с.

15.Плеснер Х. Ступени органического и человек: Введение в философскую антропологию. М.: РОСПЭН, 2004. 368 с.

16. Розов М. А. Строение научного знания (проблемы методологии и методики анализа). Философия науки. М.: ИФРАН, 1997. С. 59-87.

17.Спиноза Б. Собрание сочинений: в 2 т. М.: Госполитиздат. T. 1. $1957.640 \mathrm{c}$.

18. Степин В. С. Генезис социально-гуманитарных наук (философский и методологический аспекты). Bопросы философии. 2004. № 3. С. 37-43.

19.Философская энциклопедия: XX век. М.: АСТ, 2001. $1726 \mathrm{c}$.

20.Фролов И. Т. Избранные труды: в 3 т. М.: Наука, 2003. Т. 3.: О человеке и гуманизме. 2003. 789 с.

21.Фромм Э. Вклад Маркса в познание человека. Философия и общество. 1998. № 3. С. 234-250. 
22. Хакен Г. Основные понятия синергетики. Синергетическая парадигма. Многообразие поисков и подходов. М.: ПрогрессТрадиция, 2000. С. 28-55.

23. Хейзенга Й. Нomo ludens. Человек играющий: В тени завтрашнего дня. М.: Прогресс, 1992. 464 с.

24.Швейцер А. Благоговение перед жизнью. М.: Прогресс, 1992. $-572 \mathrm{c}$.

25.Шелер М. Положение человека в космосе. Проблема человека в западной философии. М.: Прогресс, 1988. С. 31-95.

26. Юдовская А. Я. Эволюция права в государствах Европы и Америки (XVII - XIX вв.). СПб.: Спец. лит., 1996. 164 с.

27. Якобсон Р. Избранные работы. М.: Прогресс, 1985. 370 с.

\section{Information about the author: Romanenko S. S.,}

Candidate of Philosophical Sciences, Associate Professor at the Department of Sport Games, State Institution «South-Ukrainian National Pedagogical University named after K. D. Ushynsky», 26, Staroportofrankivska str., Odesa, 65020, Ukraine 